\title{
Economic Development of Orenburg Region Innovative Potential: An Analysis of Prospective Areas
}

\author{
Olga Mikhailova \\ Orenburg State University \\ Orenburg, Russia \\ mihailova78@mail.ru
}

\begin{abstract}
In the article, the author substantiates the urgency of the need to develop the innovative potential of the Orenburg region as a territory through which the New Silk Road will pass. The problems of implementing innovations in the Orenburg region and factors contributing to and hindering radical transformations (such as technological progress, a group of growth factors of consumer requirements, factors of reducing reliability, factors of market change, factors of increasing requirements in the field of energy efficiency and environmental security) identified on the basis of statistical analysis indicate a discrepancy between the state of the territory of the Orenburg region and the requirements of the external economic environment, which requires further development of the innovative potential of the territory. It is concluded that it is necessary to implement innovative business projects on the territory of the Orenburg Region, given its border position, which facilitates access to the most effective world technologies.
\end{abstract}

Keywords: innovative potential, factors, development, territory, cross-border cooperation

\section{INTRODUCTION}

In modern economic conditions, the role of territories in pursuing their own innovative policies that meet local requirements and long-term development prospects of regional integration into international economic processes is increasing. Let us consider the need for innovative development of a region on the example of the Orenburg region as a border territory through which the New Silk Road will pass.

Currently, the center of gravity in solving strategic tasks of innovative development of Russian territories is shifted to the regions, so it is necessary to create an effective strategic planning system for regional socio-economic development that can unite the efforts of regional authorities, business leaders and society in solving problems in the region. Strengthening the dependence of the activities of planning objects on the impact of the external environment requires introduction, in fact, of a new mechanism for constructing their planned activities, which will allow combining state regulation with market principles for managing the economy through a system of economic indicators. The effectiveness of this mechanism should be determined by an adequate system of strategic, including indicative, planning that takes into account quality, complexity and high dynamics of the processes occurring both within the regional socio-economic system and in the external environment.

Thus, the design of scientific, methodological and practical recommendations for the development of the innovative potential of the region becomes particularly important in modern conditions.

\section{LiterATURE REVIEW AND RESEARCH METHODS}

The methodological basis of this study consisted of general scientific, statistical methods of economic research. Its main scientific principle is the principle of consistency, which involves the study of events and phenomena in their systemic manifestation and development-complexity, interconnection and conditioning. When conducting economic analysis, the author adhered to a systematic approach, which is due to the desire to create a holistic picture of the innovative potential of the region, to identify problems in its implementation and the logic of the analyzed processes.

A study of the essence of innovative potential was carried out in the works of such scientists as I.V. Shlyakhto, L.V. Shabaltina, T.A. Shtertser, E.P. Amosenok, V.A. Bazhanov, S.G. Alekseev, P.N. Zakharov, K.V. Nazvanova, E.P. Maskaykin, T.V. Artser and others [1-3, 9-17].

At the same time, despite the fact that works of many scientists are devoted to various aspects of the problem of the formation and implementation of a regional development strategy and there is a large number of scientific papers, this problem requires additional study and new scientific reflection considering the changes in international economic processes.

Special scientific methods that determined the structure and concept of this study were methods of dynamic deviations, comparisons, vertical and horizontal analysis. The selected methodological basis made it possible to analyze the innovative potential of the Orenburg region, identify influencing factors and determine the further vector of its development. 


\section{RESULTS}

In 2018, a large share (more than 50\%) in the structure of costs of innovative activities of the Orenburg region was occupied by the acquisition of machinery and equipment related to the introduction of technological innovations, as shown in Table I.

TABLE I. DYNAMICS OF COSTS OF TECHNOLOGICAL INNOVATIONS OF THE ORENBURG REGION BY TYPES OF INNOVATION IN 2016-2018, MILLION RUBLES

\begin{tabular}{|l|l|l|l|}
\hline Type of the innovative activity & \multicolumn{1}{|c|}{$\mathbf{2 0 1 6}$} & $\mathbf{2 0 1 7}$ & $\mathbf{2 0 1 8}$ \\
\hline $\begin{array}{l}\text { Research and development of } \\
\text { new products, services and } \\
\text { methods for their production } \\
\text { (transfer), new production } \\
\text { processes }\end{array}$ & 1761.2 & 1729.7 \\
\hline Design to & 9.5 & 3.4 & 5.7 \\
\hline $\begin{array}{l}\text { Acquisition of machinery and } \\
\text { equipment related to } \\
\text { technological innovation }\end{array}$ & 9150.9 & 5351.2 & 13350.6 \\
\hline Acquisition of new technologies & 602.7 & 701.6 & 323.3 \\
\hline $\begin{array}{l}\text { Acquisition of new capital } \\
\text { goods }\end{array}$ & 102.0 & 93.4 & 192.7 \\
\hline Engineering and training of & 4.4 & 7.9 & 12.1 \\
\hline $\begin{array}{l}\text { Education and } \\
\text { innovation-related staff }\end{array}$ & 1.7 & 0.9 & 0.5 \\
\hline Marketing research & 9.7 & 16.6 & 9.8 \\
\hline $\begin{array}{l}\text { Other technological innovation } \\
\text { costs }\end{array}$ & & & \\
\hline
\end{tabular}

Research and development of new products, services and methods for their production (transfer), new production processes in 2017 made a jump and almost doubled-from 997.3 million rubles to 1761.2 million rubles, and in 2018 this type of innovation activity remained at the level of the previous year.

The acquisition of new technologies in 2018, on the contrary, decreased by almost half_-from 701.6 million rubles to 323.3 million rubles.

Engineering covers all the stages of the innovation cycle. Engineering in 2017 decreased by almost two thirds-from 11919.3 million rubles to 3872.1 million rubles. In 2018, this type of innovative activity increased to 7468.7 million rubles. Engineering includes a complex of engineering and consulting services of a commercial nature in preparation and provision of the production process directly, maintenance of facilities, operation of economic facilities and sales of products.

Other expenses for technological innovations, including research and development, access to patent and licensing services, staff training, design, marketing research, etc., in 2018 almost halved-from 16.6 million rubles to 9.8 million rubles.

The main source of financing the costs of technological innovations in 2018 was other funds of organizations obtained by attracting loans and borrowings, $70.8 \%$ of the total cost.

An important indicator of the innovative development of the regional economy is its investment attractiveness. So, during 2015-2017, the volume of investments in fixed assets increased to six times the original amount, and in 2017 amounted to 181713.4 million rubles, which is 12470.1 million rubles more than in 2015 .

Table II presents the structure of investment in fixed assets of the Orenburg region by forms of ownership.

TABLE II. STRUCTURE OF INVESTMENTS IN FIXED ASSETS OF THE ORENBURG REGION BY FORMS OF OWNERSHIP, MILLION RUBLES. [COMPILED BY THE AUTHOR ACCORDING TO: [7, P. 265]]

\begin{tabular}{|l|l|l|l|l|}
\hline $\begin{array}{c}\text { Form of } \\
\text { ownership }\end{array}$ & \multicolumn{1}{|c|}{$\mathbf{2 0 1 5}$} & \multicolumn{1}{|c|}{$\mathbf{2 0 1 6}$} & \multicolumn{1}{|c|}{$\mathbf{2 0 1 7}$} & \multicolumn{1}{c|}{$\begin{array}{c}\text { Change (+/-) } \\
\text { 2017 to 2015 }\end{array}$} \\
\hline State & 16580.1 & 12136.7 & 9555.9 & -7024.2 \\
\hline Municipal & 6658.0 & 7039.5 & 7086.7 & +428.7 \\
\hline Private & 107743.5 & 107071.9 & 146998.8 & +39255.3 \\
\hline Foreign & 6679.0 & 6783.5 & 9826.4 & +3147.4 \\
\hline $\begin{array}{l}\text { Joint Russian } \\
\text { and foreign }\end{array}$ & 2630.1 & 3004.9 & 3395.3 & +765.2 \\
\hline
\end{tabular}

Analyzing the data in the Table II, we can conclude that in the structure of investments in fixed assets of the Orenburg region, the main place is occupied by private investments (about $80 \%$ ), state investments in fixed assets of the region during 2015-2017 tend to decrease, so in 2015 the volume of state investment amounted to 16580.1 million rubles, and in 2017 , the volume of state investment decreased by $42.4 \%$. We should note that the volume of foreign investment in fixed assets of the region for the period under review increased by $47.1 \%$.

Currently, various investment projects are being implemented in the Orenburg region; the key ones are presented in table III.

TABLE III. INVESTMENT PROJECTS IMPLEMENTED IN THE ORENBURG REGION [COMPILED BY THE AUTHOR ACCORDING TO: [8, P. 67]]

\begin{tabular}{|c|c|c|c|}
\hline Project & Project initiator & Essence & Term \\
\hline $\begin{array}{l}\text { Development of } \\
\text { the Eastern } \\
\text { section of the } \\
\text { Orenburg oil and } \\
\text { gas condensate } \\
\text { field }\end{array}$ & $\begin{array}{l}\text { Gazprom } \quad \mathrm{Neft} \\
\text { Orenburg CJSC }\end{array}$ & $\begin{array}{l}\text { Increased oil and } \\
\text { gas production }\end{array}$ & $\begin{array}{l}2013- \\
2022\end{array}$ \\
\hline \begin{tabular}{ll}
\multicolumn{2}{l}{ Implementation of } \\
a set & of \\
investment & \\
projects & to \\
modernize & \\
production & \\
\end{tabular} & $\begin{array}{l}\text { Orsknefteorgsintez } \\
\text { OJSC }\end{array}$ & $\begin{array}{l}\text { Oil refining, } \\
\text { petroleum product } \\
\text { manufacturing }\end{array}$ & $\begin{array}{l}2010- \\
2019\end{array}$ \\
\hline $\begin{array}{l}\text { Development of } \\
\text { the southern } \\
\text { railway exit from } \\
\text { the Urals to the } \\
\text { West } \\
\text { (electrification of } \\
\text { the Orenburg- } \\
\text { Krasnogvardeets- } \\
\text { Sennaya railway } \\
\text { line) }\end{array}$ & $\begin{array}{l}\text { South Ural } \\
\text { Railway-a } \\
\text { branch of Russian } \\
\text { Railways }\end{array}$ & $\begin{array}{l}\text { Increase in the total } \\
\text { cargo flow, creation } \\
\text { of additional jobs, } \\
\text { reduction of the } \\
\text { time of cargo } \\
\text { transportation in the } \\
\text { given direction, } \\
\text { increase of energy } \\
\text { efficiency of cargo } \\
\text { transportation, } \\
\text { efficient transit } \\
\text { through the Europe- } \\
\text { Russia-Kazakhstan- } \\
\text { China transit } \\
\text { complex }\end{array}$ & $\begin{array}{l}2015- \\
2019\end{array}$ \\
\hline
\end{tabular}


emergence of a number of factors that determine the need for fundamental changes in the sphere of innovations.

The results of our research indicate that the state of the territory of the Orenburg region does not meet the requirements of the external economic environment, which requires further development of the innovative potential of the territory.

Factors that determine the need for innovative transformations in the Orenburg region include: technological progress, a group of growth factors of consumer requirements, factors of reducing reliability, factors of market change, factors of increasing requirements in the field of energy efficiency and environmental security.

The economic development of the Orenburg region, as well as other regions of Russia, depends on the scientific and innovative potential, determined by the level of material, technical, labor, information and financial resources. The prospects of scientific, technical and innovative development of the regions largely depend on their capabilities and ability to create and use new technologies.

Factors of technological progress include process automation; new technologies, devices and materials; intensive growth in the number of small generating (primarily renewable) energy sources in the world.

A group of growth factors of consumer requirements are [20]: increased requirements for the selection and quality of goods and services; expectations of lowering the price parameters of goods and services of various industries; requirements for information transparency of the relationship system.

Reliability reduction factors include: increasing level of equipment wear; need for mass investment in the renovation of fixed assets; decrease in the overall level of reliability of energy supply; high level of losses in the conversion, transmission and distribution of energy.

Factors of market change are: changes in the internal conditions for the functioning of markets; economic instability; reforming of the management of industrial sector of the economy; development of the market for quotas of environmentally hazardous emissions.

Factors of increasing requirements in the field of energy efficiency and environmental safety are $[4,18,19]$ : reduction of environmental impact; increase of energy efficiency and energy saving.

Taking into account all the factors of innovative development of the Orenburg region, it is necessary to reconsider traditional approaches to the principles and mechanisms for realizing innovative potential and to develop new ones that can ensure social development, a breakthrough increase in consumer properties and the efficient use of production capacities [9].

This decision requires the development of a new concept of innovative development of the Orenburg region, which, on the one hand, would correspond to the modern views, goals and values of social and community development, the
During recent decades, the projected innovative development of the Orenburg region is characterized by the 
2) improving the conditions of border crossing and customs control;

3) regarding the development of the fuel and energy complex:

- discussing the prospects of long-term cooperation in the field of transportation and processing of natural gas and gas condensate of the Karachaganak gas condensate field in order to formulate a long-term plan for the development of capacities of Gazprom Dobycha Orenburg LLC;

- conducting negotiations on providing the Russian and Kazakhstani parties with the opportunity to conduct regional work in adjacent territories on geological studies of common geological structures for the two countries providing the information received to the country where the work was performed;

Determining the directions of development of the innovative potential of the Orenburg region, it is necessary to rely on the increasing importance of the organizational and economic potential of the territory, which significantly expands the possibilities for the speedy organization of production of new goods and services with the most efficient use of the production potential of other countries and territories.

From these positions, the formation of favorable conditions for the organization of new industries and the implementation of innovative business projects becomes the main tool for the modernization and development of the regional economic complex.

The formation of such conditions seems possible on the basis of solving two interrelated tasks - ensuring access to the most effective world technologies and to foreign financial sources.

It is necessary to develop cross-border cooperation, taking into account the special location of the Orenburg region in the southeastern part of Russia, where the New Silk Road may pass.

Recently, cross-border cooperation has become an increasingly important factor in the formation of a system of relations between neighboring countries in the socioeconomic, cultural and other fields, helping to increase the level of employment and real income of the population, creating trust and neighborliness.

In modern conditions, a sufficiently flexible mechanism for regulating cross-border cooperation is required, which would take into account both general and specific features inherent in the border territories of states.

Given the special position of the Orenburg region on the southeastern border of Russia, the innovative potential of the region and historical traditions to enhance and strengthen inter-regional cross-border cooperation of the Orenburg region in the framework of the creation of the New Silk Road, we propose the following set of measures:

1) improving the legislative and legal framework for crossborder cooperation;
- developing a joint program for geological exploration for the search, processing and transportation of hydrocarbons in the border areas;

- working out jointly with the relevant Ministry of the Republic of Kazakhstan how to provide a preferential railway tariff on the territory of Kazakhstan for the supply of iron ore and coal raw materials to the Orenburg region.

5) in the field of transport:

- transitioning to a unified policy of using transport networks that provide communication between Russia and Central Asia and communication between Kazakhstan and Central Asia through Russia and Europe, which will contribute to the necessary development of regions and the economy of the country as a whole;

- developing a plan for the implementation of agreements in the field of transport in matters of facilitating the necessary conditions for the smooth functioning of all types of transport in the border areas during the transportation of goods;

- $\quad$ supporting the idea of building a modern Moscow-Asia highway that would connect the center of Russia with Kazakhstan and other Central Asian republics. Within the boundaries of the Orenburg region, the existing highway Orenburg-Sol-Iletsk-Akbulak-Aktyubinsk may serve as a part of this highway;

6) regarding standardization and certification of products:

- conducting pre-contract certification of products in the GOST RF system by relevant organizations of the state control service of the Republic of Kazakhstan, when signing contracts between individuals, organizations and enterprises and Russian partners;

7) in the field of IT and communication:
4) in the field of engineering and metallurgy: 
[7] "The statistic yearbook of the Orenburg region. 2018", in Stat. Sat. Orenburgstat. O65, Orenburg, 2018, 530 p.

- creating a single information center for commercial market information on the issues of cross-border economic cooperation of the constituent entities of the Russian Federation on the basis of one of the line ministries, followed by the formation of such interregional centers.

In order to further develop and restructure cross-border cooperation in the future, it may be possible to implement the idea of creating Eurasian regions. The Orenburg region of the Russian Federation and the border regions of the Republic of Kazakhstan under the patronage of the European Union could act as a pilot project.

Thus, a well-developed mechanism for the innovative development of the region's economy will contribute to the formation of an effective system of strategic management of the region's development and will allow to solve a range of problems related to the rational use of regional resources and the activation of economic growth and development.

\section{REFERENCES}

[1] P.N. Zakharov and K.V. Nazvanova, "Improvement of methodological approaches to the effectiveness assessment of innovation development of regional economy," in Lecture Notes in Networks and Systems, vol. 57. Vladimir. 2019, pp. 1155-1168.

[2] C. Ponsiglione, I. Quinto, and G. Zollo, "Regional innovation systems as complex adaptive systems: The case of lagging European regions," Sustainability (Switzerland), vol. 10, issue 8, August 2018, article number 2862.

[3] O.I. Soskin, "Role of state regulation in formation of modern economic model: Changing imperative in the conditions of chaos," Economic Annals-XXI, vol. 1-2, issue 1, pp. 3-7, 2013.

[4] S.M. Suhail Hussain, F. Nadeem, M.A. Aftab, I. Ali, and T.S. Ustun, "The emerging energy internet: Architecture, benefits, challenges, and future prospects," Electronics (Switzerland), vol. 8, issue 9, September 2019, article number 1037.

[5] E.A. Surinov, "Russian statistical yearbook. 2018," in Stat. Sat. Rosstat. R76, Moscow, 2018, pp. 299-305.

[6] "Regions of Russia. Social and economic indicators. 2018," in Stat. Sat. Rosstat, Moscow, 2018, 593 p.
[8] Y.A. Semenov, "Economic evaluation of the natural resource potential of the Orenburg region," Herald of OSU, vol. 10, 2013, pp. 336-339.

[9] O.A. Stroeva, "Mechanism of coordinated management of innovation activities in the region," Regional economy: theory and practice, vol. 27(354), 2014, pp. 2-8.

[10] N.S. Necheukhina, O.V. Mustafina, and L.N. Kuklina "Competitiveness of various segments of the regional consumer market," Economy of Region, vol. 14, issue 3, 2018, pp. 836-850.

[11] I. Lyapina, M. Vlasova, O. Stroeva, O. Konobeeva, and E. Konobeeva, "Approaches to organization of project management in Russia," Contributions to Economics, 2017, pp. 91-99, № 9783319454610.

[12] A.I. Tatarkin, N.V. Krivenko, and N.L. Kuznetsova, "Dialectics of rational change management in regional social systems," Economy of Region, issue 2, 2015, pp. 125-137.

[13] O. Stroeva, N. Mironenko, A. Polyanin, I. Lyapina, and T. Lukyanchikova, "Formation of organizational directions for implementing road mapping in activities of industrial enterprises," Contributions to Economics, 2017, pp. 143-150, № 9783319606958.

[14] L. Gamidullaeva, "Neo-institutional approach for regional economic development: The impact of sociocultural determinants," International Journal of Economics and Business Administration, vol. 7, issue 2, 2019, pp. 12-25.

[15] O.A. Stroeva, Y. Zviagintceva, E. Tokmakova, E. Petrukhina, and O. Polyakova, "Application of remote technologies in education," The International Journal of Educational Management, vol. 33, issue 3, 2019, pp. 503-510.

[16] O.A. Stroeva, A.V. Gryadunova, V.V. Tishaev, I.A. Shalaev, and I.R. Lyapina, "Priorities of using the new information and communication technologies in modern economy," Advances in Intelligent Systems and Computing, vol. 726, 2019, pp. 449-455.

[17] I. Lyapina, P. Mashegov, E. Petrukhina, O. Stroeva, and A. Maltsev, "Institutional effects in development of regional innovational infrastructure," International Journal of Trade and Global Markets, vol. 12, issue 1, 2019, pp. 26-42.

[18] F. Rossi, M.L. Parisi, S. Maranghi, R. Basosi, and A. Sinicropi, "Environmental analysis of a nano-grid: A life cycle assessment," Science of the Total Environment, vol. 700, January 2020, article number 134814.

[19] E. Lisin, D. Shuvalova, I. Volkova, and W. Strielkowski, "Sustainable development of regional power systems and the consumption of electric energy," Sustainability, vol. 10, issue 4, 2018, p. 1111.

[20] A. Fedosova and I. Volkova, "Client orientation of central power Management, vol. 12, issue 1, 2018, pp. 169-188. generation companies," International Journal of Energy Sector 